\title{
PENGARUH MAKROEKONOMI TERHADAP PROFITABILITAS PERBANKAN DI INDONESIA
}

\author{
Rony Arpinto Ady
}

\begin{abstract}
ABSTRAK
Penelitian ini bertujuan untuk menganalisis pengaruh makroekonomi terhadap profitabilitas perbankan di Indonesia Pendekatan yang digunakan dalam penelitian ini adalah pendekatan penelitian kuantitatif (menggunakan data yang dapat diukur dalam suatu skala numerik/angka), dengan menggunakan data sekunder berupa data panel (pooling data) yang menggabungkan data runtut waktu (time series) dan data kerat lintang (cros section) dalam periode waktu. Sumber data yang digunakan dalam penelitian ini merupakan data sekunder. Pengumpulan data arsip berupa data sekunder menggunakan teknik pengumpulan data pengambilan basis data pooling data/ data panel (gabungan data time series dan cros section). Dalam menganalisis data, peneliti menggunakan uji regresi dengan bantuan aplikasi eviews 9. Hasil penelitian menunjukkan Pertumbuhan ekonomi/pertumbuhan pendapatan nasional berpengaruh positif dan tidak signifikan terhadap profitabilitas perbankan di indonesia. Kurs dan BI rate memiliki hubungan negatif dan tidak signifikan terhadap profitabilitas perbankan di indonesia.
\end{abstract}

Kata Kunci: Pertumbuhan Ekonomi, Kurs, BI rate, ROA

\section{ABSTRACT}

This research aims to analyze the macroeconomic influence towards banking profitability in Indonesia Approach used in this research is quantitative research approach (using data that can be measured in a scale of numeric/numbers), using secondary data in the form of panel data (pooling of data) that combines data coherently time (time series) data and kerat latitude (cros section) in that period of time. The source of the data used in this research is secondary data. Data collection the data archive in the form of secondary data collection techniques using database pooling data retrieval/data panel (combined time series data and cros section). In analyzing the data, researchers using regression test with the help of eviews application 9. The results showed economic growth/national income growth effect positive and insignificant against the profitability of banking in indonesia. Exchange rate and BI rate has a negative and insignificant relationship towards the profitability of banking in indonesia.

Keywords: economic growth, exchange rate, the $\mathrm{BI}$ rate, $\mathrm{ROA}$

\section{PENDAHULUAN}

Makroekonomi merupakan perubahan ekonomi yang mempengaruhi banyak masyarakat, perusahaan, dan pasar. Beberapa faktor makroekonomi yang mempengaruhi kondisi perbankan antara lain Inflasi, tingkat suku bunga dan GDP (Demirguc-Kunt dan
Huizinga, 2018). Menurut BI tingkat inflasi hingga akhir tahun 2018 sebesar 3,13\%. Angka ini akan lebih rendah jika dibandingkan inflasi tahun lalu 2017 yang sebesar 3,61\%. Pada periode 2015-2016, inflasi Indonesia berada dibawah kisaran 5\%. Hal ini menggerus pendapatan masyarakat sehingga menurunkan 
daya beli di dalam negeri. Namun sejak 2015, inflasi ini terus mengalami perbaikan. Dan pada tahun 2015 tingkat inflasi diperkirakan akan terus membaik. Hal ini ditandai dengan inflasi sebesar 3,35\%. Di tahun 2016 inflasi tercatat sebesar $3,02 \%$. Ini sejalan dengan target pemerintah di kisaran 4\% di tahun 2016. Dampak inflasi terhadap profitabilitas bank tergantung pada apakah inflasi diantisipasi atau tidak dan pengaruh inflasi terhadap profitabilitas bank tergantung pada apakah biaya bank dan biaya operasional lainnya meningkat pada tingkat yang lebih cepat daripada inflasi.

BI sebagai salah satu bank yang ada pada sistem perbankan nasioanal memiliki fungsi dan peran yang signifikan dalam konteks pembangunan ekonomi regional karena BI mampu membuka jaringan pelayanan di seluruh wilayah Indonesia dimana secara ekonomis. Undang-Undang No. 13 tahun 1962 tentang asas-asas Ketentuan bekerja sebagai pengembangan perekonomian daerah dan menggerakkan pembangunan ekonomi daerah untuk meningkatkan taraf kehidupan masyrakat serta menyediakan pembiayaan keuangan pembangunan di daerah, menghimpun dana serta melaksanakan dan menyimpan kas daerah (pemegang atau penyimpanan kas daerah) disamping menjalankan kegiatan bisnis perbankan.

Salah satu indikator untuk mengukur kesehatan suatu perbankan yaitu dengan mengukur profitabilitas yaitu Return On Assets (ROA). ROA merupakan rasio antara laba sesudah pajak terhadap total asset. Semakin besar ROA menunjukkan kinerja perusahaan semakin baik, karena tingkat pengembalian (return) semakin besar (Husnan, 1998). Penelitian tentang faktor yang mempengaruhi tingkat profitabilitas perbankan telah banyak dilakukan. Salah satu penelitian yang banyak digunakan sebagai acuan penelitian internasional adalah penelitian yang dilakukan oleh Demirguc-Kunt dan Huizinga pada tahun 2018. Pada penelitiannya, Demirguc-Kunt dan Huizinga menggunakan faktor makro ekonomi dan struktur keuangan suatu negara untuk melihat efek inflasi, Gross Domestic Product (GDP), pengangguran, pendapatan nasional, pertumbuhan nasional dan tingkat suku bunga terhadap profitabilitas perbankan. 
Hasil penelitian Fathunnida dkk (2017) menjelaskan dalam penelitianya bahwa GDP berpengaruh negatif signifikan terhadap Profitabilitas. Hal berbeda diungkapkan oleh Hendratno (2019) dalam penelitianya yang menyatakan bahwa PDB tidak berpengaruh signifikan terhadap profitabilitas.

Penelitian Hidayati (2014) menunjukkan bahwa kurs berpengaruh signifikan terhadap Profitabilitas bank. Hasil penelitian ini berbeda dengan penelitian Hendratno (2019) yang menyatakan kurs tidak berpengaruh signifikan terhadap profitabilitas.

Hasil penelitian Syah (2018) menunjukkan bahwa $\mathrm{BI}$ rate berpengaruh signifikan terhadap Profitabilitas sedangkan hasil penelitian Hedratno (2019) menunjukkan bahwa $\mathrm{BI}$ rate tidak berpengaruh signifikan terhadap Profitabilitas Bank.

Berdasarkan permasalahan yang terjadi maka peneliti mencoba untuk menganalisis pengaruh makroekonomi terhadap profitabilitas perbankan di Indonesia dimana makroekonomi meliputi pertumbuhan pendapatan, kurs rupiah, dan BI rate dan profitabilitas meliputi ROA.

\subsection{Rumusan Masalah}

Berdasarkan latar belakang yang telah diuraikan tersebut, maka rumusan masalah dalam penelitian ini adalah:

1. Bagaimanakah pengaruh pertumbuhan ekonomi terhadap ROA ?

2. Bagaimanakah pengaruh kurs terhadap ROA ?

3. Bagaimanakah pengaruh BI rate terhadap ROA ?

\subsection{Tujuan Penelitian}

1. Untuk mengetahui pengaruh pertumbuhan ekonomi terhadap ROA

2. Untuk mengetahui pengaruh kurs terhadap ROA

3. Untuk mengetahui pengaruh $\mathrm{BI}$ rate terhadap ROA

\section{TELAAH LITERATUR}

\section{Makroekonmi}

Makroekonomi dapat

membantu memahami dan menyelesaikan masalah terkait perekonomian, dan juga sebagai alat untuk menentukan arah kebijakan yang akan diambil. Teori ekonomi makro membahas tentang beberapa hal, diantaranya; penentuan kegiatan perekonomian, inflasi, tingkat pengangguran, kebijakan pemerintah, dan hal lain yang berkaitan dengan perekonomian secara keseluruhan. 
1.1 Pertumbuhan Ekonomi

Menurut Sadano Sukirno (2012) pertumbuhan ekonomi merupakan perubahan tingkat kegiatan ekonomi yang berlaku dari tahun ke tahun. Sehingga untuk mengetahuinya harus diadakan perbandingan pendapatan naional dari tahun ke tahun, yang dikenal dengan laju pertumbuhan ekonomi. Dalam penelitian ini pertumbuhan ekonomi diukur dengan pertumbuhan GDP. GDP merupakan jumlah nilai tambah yang dihasilkan oleh seluruh unit usaha dalam suatu negara tertentu. Dalam penelitian ini digunakan pertumbuhan GDP atas dasar harga konstan dimana nilai tersebut merupakan nilai tambah barang dan jasa yang dihitung enggunakan harga yang berlaku pada satu tahun ertentu sebagai dasar. Perhitungan pertumbuhan GDP dengan dengan tahun dasar adalah sebagai berikut :

$R_{(t-1, t)}=\frac{P D B_{t}-P D B_{t-1}}{P D B_{t-1}} X 100 \%$

$R_{(1-1, t)}=$ Tingkat Pertumbuhan ekonomi yang ditan yakan dalam persentase $P D B_{t}=$ Pendapa $\tan$ Domestic Bruto tahun $t$

$P D B_{t-1}=$ Pendapa $\tan$ Domestik Bruto tahun dasar
1.2 Kurs

kurs atau nilai tukar adalah harga suatu mata uang terhadap mata uang lainnya ( Salvatore, 1997:10). Kurs valas yang diterapkan dalam penelitian ini ialah perubahan kurs tengah US\$.

$$
\mathrm{NTt}=\frac{K t-K t-1}{K t-1} \times 100
$$

\subsection{BI rate}

Menurut Bank Indonesia, BI rate adalah suku bunga kebijakan yang mencerminkan sikap atau stance kebijakan moneter yang ditetapkan oleh Bank Indonesia dan diumumkan kepada publik. BI rate diumumkan oleh Dewan Gubernur Bank Indonesia setiap Rapat Dewan Gubernur bulanan dan diimplementasikan pada operasi moneter yang dilakukan Bank Indonesia melalui pengelolaan likuiditas (liquidity management) di pasar uang untuk mencapai sasaran operasional kebijakan moneter.

\section{Profitabilitas}

\section{Profitabilitas}

adalah

kemampuan suatu perusahaan untuk memperoleh laba yang menjadi tujuan perusahaan. Tingkat keuntungan bersih (net income) yang dihasilkan oleh bank dipengaruhi oleh faktor-faktor yang dapat 
dikendalikan (controlable factor) dan faktor yang tidak dapat dikendalikan (uncontrolable factor). Controlable factor adalah faktor-faktor yang dapat dipengaruhi oleh manajemen seperti segmentasi bisnis (orientasi pada wholesale dan retail), pengendalian pendapatan (tingkat bagi-hasil, keuntungan atas transaksi jual beli, biaya-biaya). Uncontrolable factor atau faktor-faktor eksternal adalah faktor yang mempengaruhi kinerja bank seperti kondisi ekonomi secara umum dan situasi persaingan di lingkungan wilayah operasionalnya. Bank tidak dapat mengendalikan faktor-faktor eksternal, tetapi mereka dapat membangun fleksibilitas dalam rencana operasional bank dalam menghadapi faktor eksternal. Ada dua rasio yang dipakai dalam mengukur kinerja bank, yaitu Return on Assets (ROA) merupakan perbandingan antara pendapatan bersih dengan rat-rata aktiva dan Return on Equity (ROE) merupakan perbandingan antara pendapatan bersih dengan rata-rata modal arau investasi para pemilik bank (Ariffin, 2015).

Return on Assets (ROA) meupakan rasio yang menunjukan kemampuan dari modal yang diinvestasikan dalam kesluruhan aktiva untuk menghasilkan keuntungan Menggambarkan produktivitas bank bersangkutan, berapa banyak kekayaan yang harus dikumpulkan dan dipakai untuk menghasilkan sejumlah laba tertentu (Santoso, 2015). Menurut Bank Indonesia ROA merupakan perbandingan antara laba sebelum pajak degan rata-rata total aset dalam suatu periode.

$$
R O A=\frac{\text { Laba Sebelum Pajak }}{\text { Total Assets }}
$$

\section{Pengaruh}

Pertumbuhan

\section{Ekonomi Terhadap ROA}

$$
\text { Menurut Sukirno (2010) }
$$

pertumbuhan ekonomi merupakan kenaikan GDP pada satu tahun tertentu yang dibandingkan dengan periode sebelumnya GDP merupakan pertumbuhan ekonomi disuatu negara serta indikator kesejahteraan masyarakat, sehingga apabila GDP naik maka akan meningkatkan kinerja perbankan yang merupakan salah satu unit ekonomi (Madura,2007 dalam Nufus,2014). Suteja dan Gerinata (2014) menjelaskan bahwa semakin tinggi tingkat pertumbuhan GDP, maka tingkat profitabilitas bank juga akan meningkat. Pertumbuhan GDP akan meningkatkan permintaan 
kredit perbankan, hal ini dikarenakan kegiatan ekonomi mengalami peningkatan produksi yang membutuhkan sumber pembiayaan dan ini dapat diberikan bank melalui penyaluran kredit. Dengan meningkatnya permintaan kredit, maka bank akan memperoleh peningkatan laba dari bunga kredit yang akhirnya akan meningatkan profitabilitas bank. Sehingga Hipotesis pertama di rumuskan sebagai berikut :

H1 : Pertumbuhan Ekonomi berpengaruh signifikan positif terhadap ROA

\section{Pengaruh Kurs Terhadap ROA}

Menurut Arifi dalam Putra (2009:43) Apabila terdepriasi rupiah terhadap dollar maka akan berdampak pada penurunan Profitabilitas bank. Nilai tukar mengalami depresiasi atau kelemahan rupiah terhadap dollar, perusahaan akan mengurangi biaya ekspor, sehingga akan membuat laba perusahaan menurun, dan perusahaan tidak dapat memperoleh kredit dari bank untuk mengembangkan usahanya dan menyebabkan biaya pinjaman atau kewajiban yang harus di bayar menjadi naik dan membuat profitabilitas bank menurun. Berdasarkan teori dan penelitian terdahulu bahwa nilai tukar berpengaruh negatif dan signiifikan. $\mathrm{H} 2$ : Kurs berpengaruh signifikan negatif terhadap ROA

\section{Pengaruh BI Rate Terhadap ROA}

Dalam menentukan tingkat bagi hasil baik dalam pendanaan maupun pembiayaan, bank syariah masih mengacu kepada tingkat suku bunga umum sebagai equivalent rate atau masih dijadikan benchmark dalam penentuan margin bagi hasil (profit sharing). Menurut Karim (2006), BI Rate juga ikut mempengaruhi profitabilitas bank. Ketika suku bunga BI naik, maka akan di ikuti oleh naiknya suku bunga deposito yang berakibat langsung terhadap penurunan sumber dana pihak ketiga bank syariah. Penurunan DPK ini sebagai akibat dari pemindahan dana masyarakat ke bank konvesional untuk mendapatkan imbalan bunga lebih tinggi. Apabila DPK turun maka Profitabilitas Bank Syariah juga akan mengalami penurunan.

$\mathrm{H} 3$ : $\mathrm{BI}$ rate berpengaruh signifikan negatif terhadap ROA

\section{METODOLOGI PENELITIAN}

Pendekatan yang digunakan dalam penelitian ini adalah pendekatan penelitian kuantitatif (menggunakan data yang dapat 
diukur dalam suatu skala numerik/angka), dengan menggunakan data sekunder berupa data panel (pooling data) yang menggabungkan data runtut waktu (time series) dan data kerat lintang (cros section) dalam periode waktu. Sumber data yang digunakan dalam penelitian ini merupakan data sekunder. Pengumpulan data arsip berupa data sekunder menggunakan teknik pengumpulan data pengambilan basis data pooling datal data panel (gabungan data time series dan cros section). Dalam menganalisis data, peneliti menggunakan uji regresi dengan bantuan aplikasi eviews 9 .

Populasi dalam penelitian ini adalah bank syariah yang terdaftar di Bank Indonesia pada tahun 20152018. Sampel penelitian diambil secara purposive sampling yaitu metode dimana pemilihan sampel pada karakteristik populasi yang sudah diketahui sebelumnya dengan kriteria sebagai berikut :
1. Bank syariah merupakan Bank Umum Syariah (BUS).

2. Bank Syariah tersebut membuat laporan keuangan tahunan pada periode 2015-2018 dan telah dipublikasikan di Bank Indonesia.

3. Data untuk penelitian tersedia antara tahun 2015-2018. Dari kriteria diatas terdapat 12 bank umum syariah yang digunakan dalam penelitian ini.

\section{TEKNIK ANALISIS DATA}

Teknik analisis yang digunakan dalam penelitian ini adalah teknik analisis regresi linier berganda. Persamaan regresi linier berganda dalam penelitian ini adalah sebagai berikut: $\mathrm{Y}=\mathrm{a}+\mathrm{b} 1 \mathrm{X} 1+\mathrm{b} 2 \mathrm{X} 2+\mathrm{b} 3 \mathrm{X} 3+\mathrm{e}$

Dimana:

$\mathrm{Y}=$ Return On Asset (ROA)

$\mathrm{a}=$ Konstanta

$\mathrm{X} 1$ = Pertumbuhan Ekonomi

$\mathrm{X} 2=$ Kurs

$\mathrm{X} 3=\mathrm{BI}$ rate

b1, b2, b3 = koefisien regresi

$\mathrm{e}=$ error

\section{HASIL DAN PEMBAHASAN}

Tabel 1. Hasil UJI Regresi dengan eviews

Dependent Variable: ROA

\begin{tabular}{|l|c|c|c|c|}
\hline Variable & Coefficient & Std. Error & t-Statistic & Prob. \\
\hline GDPGR & 0.142597 & 0.102379 & 1.217020 & 0.1367 \\
\hline D(KURS) & -0.000676 & 0.000274 & -0.105132 & 0.0765 \\
\hline D(BIRATE,2) & -0.342010 & 0.444655 & -0.724179 & 0.4458 \\
\hline C & 2.148 .931 & 0.190376 & 1.728 .785 & 0.0000 \\
\hline
\end{tabular}

Sumber: hasil olah data dengan eviews, 2018 
1. Pengaruh

Pertumbuhan

Pendapatan

Nasional

(Pertumbuhan Ekonomi) terhadap

Profitabilitas Perbankan

Setelah dilakukan olah dan analisis data diperoleh nilai koefisien $\beta$ sebesar 0,142597 ; $t$ hitung $1,217<1,680$ t-tabel; signifikansi $0,1367>0,05$. Menyatakan bahwa pertumbuhan pendapatan nasional berpengaruh positif dan tidak signifikan terhadap profitabilitas perbankan. Hasil dari penelitian ini didukung oleh penelitian Ariffin dan Fauziah (2014) yang menyatakan bahwa GDP tidak menunjukkan dampak yang signifikan terhadap laba perbankan. Penelitian lain dari Abduh dan Yameen (2013) GDP tidak signifikan dan memiliki hubungan negatif terhadap profitabilitas perbankan. Teng et al (2012) menunjukkan bahwa GDP dan profitabilitas memiliki hubungan tidak signifikan. Macit (2012) menyebutkan hasil penelitian bahwa pertumbuhan GDP memiliki dampak positif dan tidak signifikan terhadap profitabilitas. Sedangkan penelitian lain menyebutkan hasil yang bertentangan dengan penelitian ini, Osamwonyi (2014) menyebutkan GDP secara statistik memiliki hubungan signifikan dengan profitabilitas perbankan. Widyaningrum dan Dodik (2014) menyatakan bahwa pertumbuhan GDP memiliki pengaruh negatif dan signifikan terhadap ROA. Mukhlis (2012) menemukan hasil penelitian pertumbuhan ekonomi memiliki pengaruh positif dan signifikan terhadap tingkat profitabilitas yang dapat diperoleh perbankan di Indonesia.

Pertumbuhan pendapatan nasional memiliki hubungan positif dengan profitabilitas perbankan. Kenaikan pertumbuhan pendapatan nasional akan memicu naiknya kegiatan ekonomi masyarakat secara umum (pelaku ekonomi) kenaikan kegiatan ekonomi tersebut dapat berdampak pada kenaikan kegiatan yang dilakukan oleh bank dalam memberikan layanan pada masyarakat sehingga pada akhirnya dapat meningkatkan pendapatan perbankan. 
2. Pengaruh Kurs terhadap Profitabilitas Perbankan

Setelah dilakukan olah dan analisis data diperoleh nilai koefisien $\beta$ sebesar -0,000676; thitung $0,105<1,687$ t-tabel; signifikansi $0,0765>0,05$. Variabel kurs berpengaruh negatif dan tidak signifikan terhadap profitabilitas bank umum Perbankan. Hasil dari penelitian ini didukung oleh penelitian Pratama (2015) yang menyebutkan kurs rupiah terhadap dolar mempengaruhi performa Perbankan. Adebola et al (2011) menyatakan hasil yang searah dengan penelitian ini bahwa nilai tukar tidak berpengaruh signifikan pada jangka panjang. Sedangkan penelitian lain Dwijayanti dan Prima (2009) menghasilkan kesimpulkan nilai tukar uang berpengaruh negatif dan signifikan terhadap profibilitas Perbankan. Macit (2012:591) menyimpulkan log kurs memiliki dampak positif dan signifikan terhadap performa perbankan. Krisis nilai tukar berpengaruh negatif terhadap perekonomian, mengakibatkan harga-harga melambung tinggi.
Melemahnya nilai tukar mengakibatkan barang-barang impor menjadi lebih mahal dan mengakibatkan kenaikan hargaharga di dalam negeri, kemudian berdampak pada turunnya kemampuan masyarakat untuk menabung dan investasi karena dana yang dimiliki telah dialokasikan untuk memenuhi kebutuhan pokok.

3. Pengaruh BI rate terhadap Profitabilitas Perbankan Setelah dilakukan olah dan analisis data diperoleh nilai koefisien $\beta$ sebesar -0,342010; thitung $0,724<1,687$ t-tabel; signifikansi $0,4458>0,05$. BI rate berpengaruh negatif dan tidak signifikan terhadap profitabilitas Perbankan. Hal ini terjadi karena kegiatan operasinal Perbankan syariah tidak menggunakan prinsip bunga dan lebih mengutamakan pada operasional yang mendukung kegiatan ekonomi sektor riil. Vejzagic dan Haseem (2014) menyimpulkan hasil penelitian bahwa suku bunga rill tidak memiliki hubungan dengan profitabilitas Perbankan, sedangkan Adebola et al (2011) menyatakan dampak negatif 
suku bunga terhadap pembiayaan Perbankan dalam penelitiannya. Hasil lain dari penelitian Pratama (2015), suku bunga mempengaruhi performa Perbankan. Osamwonyi dan Chijuka (2014) suku bunga memiliki hubungan signifikan. Hasil dari penelitian ini bertentangan pula dengan hasil penelitian Macit (2012) menyatakan suku bunga memiliki dampak positif dan signifikan terhadap performa Perbankan. Prinsip bunga tidak diterapkan dalam Perbankan, namun dalam praktiknya penetapan bagi hasil atas tabungan dan investasi nasabah mengacu pada besarnya suku bunga Perbankan. Meningkatnya suku bunga dapat berdampak baik pada tabungan tetapi berbanding terbalik dengan pembiayaan yang diberikan Perbankan. Sementara pendapatan Perbankan tidak hanya diperoleh melalui penghimpunan dana saja namun juga pendapatan lain berupa bagi hasil melalui kegiatan penyaluran dana (pembiayaan). Jika pendapatan bagi hasil pembiayaan menurun tanpa diimbangi kenaikan pendapatan dari pos lain maka akan mempengaruhi besarnya laba yang mampu dihasilkan Perbankan.

\section{KESIMPULAN}

Berdasarkan hasil penelitian dapat disimpulkan sebagai berikut:

1. Pertumbuhan ekonomi/pertumbuhan pendapatan nasional berpengaruh positif dan tidak signifikan terhadap profitabilitas perbankan di indonesia.

2. Kurs dan BI rate memiliki hubungan negatif dan tidak signifikan terhadap profitabilitas perbankan di indonesia.

\section{DAFTAR PUSTAKA}

Abduh, Muhamad and Idrees, Yameen, Determinants of Islamic Banking Profitability in Malaysia, Australian Journal of Basic and Applied Sciences, 7 (2) : 204-210, 2013.

Adebola, Yousaf and Dahalan (2011), "The Impact of Macroeconomic Variables on Islamic Banks Financing in Malaysia", Research Journal of Finance and Accounting, Vol 2, No 4

Algifari, S. A. 2013. Ekonomi Mikro-Makro Teori, Soal, dan Jawaban Edisi Keempat. 
Yogyakarta:

Yogyakarta.

Antonio, M. Syafi'i. 2001. Bank Syariah dari Teori ke Praktek, Jakarta: Gema Insani Press.

Ariffin, Anas.F dan Fauziah Hanim Tafri. 2014. The Impact of Financial Risk on Islamic Bank's Profitability. International Conference of Business, Sociology, and Applied Sciences: 26-27.

Arifin, Z. 2009. Dasar-Dasar Manajemen Bank Syariah Edisi Revisi. Ciputat: Azkia Publisher.

Bawono, Anton. 2006. Multivariate Analysis dengan SPSS, Salatiga: STAIN Salatiga Press.

Demirguc-kunt, A. \& Huizinga, H. (1999). Determinants of Commercial Bank Interest Margins and Profitability: Some International Evidence. Worl Bank Economic Review, 13 (2): 379-408.

Dwijayanthy $F$ dan Naomi $P$, "Analisis Penagruh Inflasi, BI Rate dan Nilai Tukar Mata Uang Terhadap Profitabilitas Bank Periode 2003-2007", KarismA, Vol. 3, No. 2, 2009.

F Macit, 2012, Bank Specific And Macroeconomic Determinants Of Profitability : Evidence from Participation Bank in Turkey, Economics Bulletin 32 (1), $585-595$.

Ghozali, I, 2013, Aplikasi Analisis Multivariate dengan Program IBM SPSS 21 Update PLS Regresi Edisi Ketujuh. Semarang: Badan Penerbit Universitas Diponegoro.
Hendratno dan Alex Winarno, 2019, Pengaruh Variabel Eksternal Terhadap Return On Aset (Studi Kasus Bank Umum Syariah Yang Terdaftar Di BEI Periode 2012-2017), Jurnal ManajemenIndonesia Vol 19 (2).

Hidayati, Amalia Nuril, 2014, Pengaruh Inflasi, BI rate Dan Kurs Terhadap Profitabilitas Bank Syariah Di Indonesia, Jurnal An-nisbah Vol 01 No 01

Husnan, Suad, 1998, Dasar-Dasar Teori portofolio. Yogyakarta: AMP YKPN. 2001. DasarDasar Portofolio dan Analisis Sekuritas, Edisi 3. AMP YKPN, Yogyakarta.

Isna $\mathrm{K}$, Andryani dan Kunti Sunaryo, 2012, Analisis Pengaruh Return On Asset, BOPO, dan Suku Bunga terhadap Tingkat Bagi Hasil Deposito Mudharabah pada Bank Umum Syariah. Ekonomi dan Bisnis 11 (01): 29-42.

Karim, Adiwarman A. 2006. Ekonomi Makro Islam. PT. Rajagrafindo Persada. Jakarta.

Leon, B. \& Ericson, S. 2008. Manajemen Aktiva Pasiva Bank Devisa . Jakarta : Grasindo

Madura, Jeff. 2006. Keuangan Perusahaan Internasional, Edisi Kedelapan.Jakarta:Salemba Empat.

Osamwonyi, Ifuero Osad dan Chijuka Ify Michael, 2014, The Impact Of Macroeconomic Variables On The Profitability Of Listed Commercial Bank In Nigeria, European Journal Of Accounting Auditing And 
Finance Research Vol 2 No 10, PP 85-95.

Prastowo D, Analisis Laporan Keuangan: Konsep dan AplikasiI, Edisi Ketiga Cetakan Pertama, Yogyakarta: UPP Sekolah Tinggi Ilmu Manajemen YKPN, 2011.

Vejzagic, Mirza dan Hashem Zarafat, 2013, Relationship Between Macroeconomic Variables and Stock Market Index: CoIntegration Evidence From FTSE Bursa Malaysia Hijrah Shariah Index, Asian Journal of Management Science and Education, Vol.2 No.4 hal.94-108, October 2013 ISSN:2186-845X

Salvatore, Dominic. 1997. Ekonomi Internasional. Jakarta : Penerbit Erlangga

Santoso, Ruddy Tri. 2015, Prinsip Dasar Akuntansi Perbankan, Yogyakarta: Andi Offset.

Sukirno,Sadono, 2012, Makroekonomi: Teori
Pengantar, Jakarta: Rajawali Pers.

Suryakusuma K.H dan Asri Nur Wayuni, 2018, Dampak Makro Ekonomi Dan Faktor Internal Terhadap Kinerja Keuangan Bank Umum Syariah Di Indonesia, JWEM Vol 8 No 02 Oktober 2018.

Toufan A Syah, 2018, Pengaruh Inflasi, BI Rate, NPF, Dan BOPO Terhadap Profitabilitas Bank Umum Syariah Di Indonesia, Jurnal Ekonomi Islam el- Jizya Vol 6 No 1

Widyaningrum L dan Siswantoro D, "Analysis the Effect of Macroeconomic Indicators and Specific-Firm Characteristic as Determinant Profitability of Islamic Banks in Asia", Global Review of Islamic Economic and Business, Vol. 2, No. 2, 2014 